\title{
AQbD Driven Development of an RP-HPLC Method for the Quantitation of Abiraterone Acetate for its Pharmaceutical Formulations in the Presence of Degradants
}

\author{
Degradantların Varlığında Farmasötik Formülasyonları için Abirateron \\ Asetat Miktarının Belirlenmesi için AQbD Güdümlü Bir RP-HPLC \\ Yönteminin Geliştirilmesi
}

\author{
(D) Bikash Ranjan JENA1,2*, (D) Siva Prasad PANDA², (D) Umasankar KULANDAIVELU2, (D) Rajasekhar Reddy ALAVALA², \\ (D) G.S.N Koteswara RAO², (D) Suryakanta SWAIN ${ }^{3}$, (D) Gurudutta PATTNAIK1, (D) Debashish GHOSE 4 \\ 1School of Pharmacy and Life Sciences, Centurion University of Technology and Management, Odisha, India \\ 2KL College of Pharmacy, Koneru Lakshmaiah Education Foundation, Andhra Pradesh, India \\ 3Department of Pharmacy, School of Health Sciences, The Assam Kaziranga University, Koraikhowa, Assam, India \\ 4Department of Pharmaceutics, Roland Institute of Pharmaceutical Sciences, Odisha, India
}

\begin{abstract}
Objectives: Abiraterone acetate is a well-known anticancer drug and a steroidal derivative of progesterone for treatment of patients with hormonerefractory prostate cancer. Chemometrics-assisted reverse phase high performance liquid chromatography (RP-HPLC) development of the drug abiraterone acetate has been employed in this study using an analytical quality by design ( $\mathrm{AQbD}$ ) approach.

Materials and Methods: Drug separation was performed using a Princeton Merck-Hibar Purospher STAR (C18, $250 \mathrm{~mm} \times 4.6 \mathrm{~mm})$ i.d., $5 \mu \mathrm{m}$ particle size) with ultraviolet detection at $235 \mathrm{~nm}$. A Box-Behnken statistical experimental design with response surface methodology was executed for method optimization and desired chromatographic separation from its formulation with a few numbers of experimental trials. The impact of three independent variables, namely, composition of the mobile phase, $\mathrm{pH}$, and flow rate, on response retention time and peak area was studied by constructing an arithmetic model from these variables.

Results: Optimized experimental conditions for the proposed work include the mobile phase acetonitrile and phosphate buffer $\left(10 \mathrm{mM} \mathrm{KH}_{2} \mathrm{PO}_{4}\right.$ ) $(20: 80 \% \mathrm{v} / \mathrm{v})$. At the concentration range of $2-100 \mu \mathrm{g} / \mathrm{mL}$, a linear calibration curve was found. Recovery was performed at three concentrations and was foun to be between $98 \%$ and $102 \%$. The $3 \mathrm{D}$ response surface curves revealed that mobile phase composition and flow rate were the most substantial critical factors affecting desired responses.

Conclusion: An attempt has been made to develop and validate an economical, precise, robust, stability-indicating AQbD-based RP-HPLC method that can be employed successfully for the routine analysis of abiraterone acetate in quality control labs.
\end{abstract}

Key words: Precision, accuracy, ICH guidelines, method validation, experimental design

\footnotetext{
*Correspondence: bikashranjan.jena97@gmail.com, Phone: +91 (0674) 2596228, ORCID-ID: orcid.org/0000-0001-9722-4454

Received: 05.02.2021, Accepted: 12.03.2021

๑Turk J Pharm Sci, Published by Galenos Publishing House.
} 
Amaç: Abirateron asetat, iyi bilinen bir antikanser ilacıdır ve hormona dirençli prostat kanseri olan hastaların tedavisi için progesteronun steroidal bir türevidir. Bu çalışmada abirateron asetat ilacının kemometri destekli ters fazlı yüksek performanslı sıvı kromatografisi (RP-HPLC) ile geliştirmesi, analitik kalite tasarım (AQbD) yaklaşımı kullanılarak gerçekleştirilmiştir.

Gereç ve Yöntemler: İlaç ayrımı, 235 nm'de ultraviyole saptamalı bir Princeton Merck-Hibar Purospher STAR (C18, 250 mm x 4,6 mm) i.d., 5 um partikül boyutu) kullanılarak yapılmıştır. Tepki yüzeyi metodolojisine sahip bir Box-Behnken istatistiksel deney tasarımı, yöntem optimizasyonu ve birkaç deneysel deneme ile formülasyonundan istenen kromatografik ayırma için uygulanmıştır. Üç bağımsız değișkenin, yani mobil fazın bileşimi, pH ve akış hızının, yanıt tutma süresi ve tepe alanı üzerindeki etkisi, bu değișkenlerden bir aritmetik model olușturularak incelenmiștir.

Bulgular: Önerilen çalışma için optimize edilmiş deneysel koşullar, mobil faz asetonitril ve fosfat tamponunu $\left(10 \mathrm{mM} \mathrm{KH_{2 }} \mathrm{PO}_{4}\right)(20: 80 \% \mathrm{~h} / \mathrm{h})$ içerir. 2-100 $\mathrm{\mu g} / \mathrm{mL}$ konsantrasyon aralığında doğrusal bir kalibrasyon eğrisi bulunmuştur. Geri kazanım, üç konsantrasyonda gerçekleştirilmiş ve \%98 ile \%102 arasında bulunmuştur. 3B yanıt yüzey eğrileri, mobil faz bileșimi ve akış hızının, istenen yanıtları etkileyen en önemli kritik faktörler olduğunu ortaya çıkarmıştır.

Sonuç: Kalite kontrol laboratuvarlarında abirateron asetatın rutin analizi için başarıyla kullanılabilecek ekonomik, kesin, sağlam, stabiliteyi gösteren AQbD tabanlı RP-HPLC yöntemini geliştirmek ve doğrulamak için bir girişimde bulunulmuştur.

Anahtar kelimeler: Kesinlik, doğruluk, ICH yönergeleri, yöntem validasyonu, deneysel tasarım

\section{INTRODUCTION}

The potent anticancer drug abiraterone acetate $\{[(3 S, 8 R, 9 S, 10 R, 13 S, 14 S)-10,13$-dimethyl-17-pyridin-3-yl$2,3,4,7,8,9,11,12,14,15$-decahydro-1H-cyclopenta[a]phenanthren3-yllacetate\} is an acetyl ester and a significant prodrug of its active metabolite abiraterone. ${ }^{1-3}$ It is a well-built receptor blocker of androgen with potent bioavailability, especially in oral administration. ${ }^{4}$ Abiraterone acetate is found to be more intense and effective than ketoconazole and liarozole in CYP17A1 inhibition; which is a rate-limiting enzyme for the biosynthesis of androgens. 4,5 Principally, abiraterone acetate is specified for use in combination with prednisone for treatment of men with metastatic castration-resistant prostate cancer who have already received prior chemotherapy comprising docetaxel. ${ }^{5}$ Abiraterone acetate is poorly soluble over an extensive $\mathrm{pH}$ range. However, it is faintly soluble in $\mathrm{HCl}$ as well as in organic solvents (Figure 1). Abiraterone acetate can be detected by liquid chromatography-tandem mass spectrometry, ${ }^{6-8}$ spectrofluorimetric for measuring fluorescence emission, and absorption spectroscopy in cancer patients. ${ }^{9-11}$ Furthermore, the drug has been thoroughly recognized by other chromatographic techniques for the quantification of metabolites in biological samples bioanalytically. $8,9,12$ However, there is scant research using QbD Paradigm, MODR Concepts, design space, and systematic development by chemometrics-assisted statistical

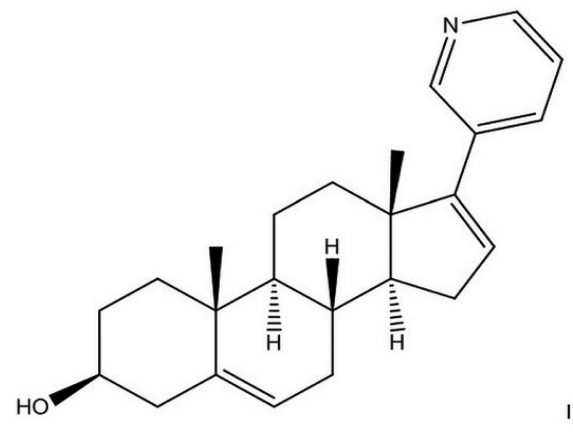

optimization of critical method parameters (CMPs) and critical method attributes. ${ }^{13}$ These optimization techniques with analytical quality by design ( $A Q b D$ ) are efficient, cost-effective, and innovative methodologies, which signify the "finest solution" to a meticulous "complexity" or problems raised in method development but deliver consistent quality output where other general High-performance liquid chromatography (HPLC) methods have been unable to achieve. ${ }^{13-16}$ Notably, more relatively efficient optimization techniques such as BoxBehnken design (BBD) than other designs (central composite, d-optimal, and mixture design) have been applied for analytical method development and optimization of pharmaceutical drugs. BBD is a second-order three-level factorial design with advantages of user-friendly, economical, simple, and limited experimental runs. ${ }^{17,18}$ Apart from that, such BBD optimization is a sequential design empowered with a feasible design matrix showing the quadratic model with a straightforward assessment of CMPs or critical material attributes. It also requires limited variables or responses, mainly three coded levels such as [low $(-1)$, middle $(0)$, and high $(+1)$ ], for the experimental design to fit the statistics or lack of fit values of the distinctive quadratic model. ${ }^{17-19}$ Therefore, the developed method of validation, optimization, and stability-indicating reversed-phase (RP)-HPLC by employing the AQbD approach for the quantification of the bulk drug and its pharmaceutical formulations of abiraterone acetate is more economical, robust, and less expensive and reduces the heat and trial methods of optimization as well as the revalidation process as compared to one factor-at-a-time approach.

\section{MATERIALS AND METHODS}

A pure standard of the drug abiraterone acetate was obtained from Sun Pharmaceutical Industries Ltd., Halol, Gujarat, India. Abiraterone acetate was obtained commercially [XIBRA (Cipla Ltd, India), ZYTIGA (Janssen-Cilag Ltd., India), and ABIRAPRO (Glenmark Pharmaceuticals, India)] with a labeled claim of $250 \mathrm{mg}$. Phosphate buffer and acetonitrile (HPLC grade) were procured from Merck Laboratories, Mumbai. 


\section{Instrumentation}

A Shimadzu HPLC system (LC-2010C HT) with a ultraviolet (UV)-visible detector, ultra-sonicator from Remi Instruments, Mumbai, and nylon filter $(0.45 \mu \mathrm{m})$ from Millipore, Mumbai, India, was used.

\section{Chemicals and reagents}

Orthophosphoric acid (OPA) (AR grade) and acetonitrile (HPLC grade) were obtained from Merck Laboratories Pvt. Ltd., Mumbai. Potassium dihydrogen phosphate $\left(\mathrm{KH}_{2} \mathrm{PO}_{4}\right)$ was obtained from Fischer Scientific, Mumbai, India.

\section{Methods}

Method optimization was performed with Box-Behnken statistical design comprising the CMPs, which include three significant factors (the composition of the determined mobile phase, flow rate, and $\mathrm{pH}$ of buffer), encompassing three levels. Seventeen experimental runs were established with five center points. The flow rate was tested at $1.0,1.2$, and $1.5 \mathrm{~mL} / \mathrm{min}$; the $\mathrm{pH}$ was measured at 4, 5, and 6; and the concentration of the mobile phase was monitored at $20 \%, 50 \%$, and $80 \%$. The responses considered were retention time (Rt) and peak area, which were designated as critical analytical attributes (CAAs). The data were analyzed, and the model was validated with Design-Expert software. The quadratic model revealed a virtuous correlation with the experimental data executed for design space navigation. The 2D \& 3D response surface techniques and perturbation sequential plots were scrutinized to assess the indicative critical factors' impact upon the observed responses or CAAs found within the predicted range. The predicted values from the practical responses were found to be satisfactory, and it was confirmed that it was acquired within the design space of the optimized results..$^{19,20}$

\section{Statistical analysis}

Design-Expert (Version 12), Stat-Ease Inc., Minneapolis, MN, USA, was utilized for method optimization and estimation of its CMPs and randomization of the runs. ${ }^{14}$ Microsoft Excel 2007 (Microsoft, USA) was used for the remaining calculations.

\section{Preparation of solvent}

Phosphate buffer ( $\mathrm{pH} 4$ ): Disodium hydrogen phosphate (5.04 g) and $\mathrm{KH}_{2} \mathrm{PO}_{4}(3.01 \mathrm{~g})$ were dissolved in water to a volume of $1000 \mathrm{~mL}$. The $\mathrm{pH}$ was adjusted to 4.0 with OPA. The resulting solution was passed through $(0.45 \mu \mathrm{m})$ filter paper, filtered by vacuum filtration, and sonicated for about 15 min. ${ }^{15}$ While preparing the mobile phase, only the phosphate buffer was filtered using $(0.45 \mu \mathrm{m})$ nylon membrane filters. Acetonitrile was not filtered and was used as provided by the supplier.

\section{Procedure for the stock standard solution}

Standard stock solution of the drug was made by accurately weighing $10 \mathrm{mg}$ of the drug and mixed with $10 \mathrm{~mL}$ of acetonitrile to acquire a concentration of $1000 \mu \mathrm{g} \mathrm{mL}^{-1}$. Serial dilutions of the stock solution were prepared by diluting with the mobile phase to obtain concentrations of 1 to $100 \mu \mathrm{g} \mathrm{mL}^{-1}$ and filtered through a $0.45 \mu \mathrm{m}$ syringe filter before chromatography.
Calibration curves were constructed as depicted in Figures 2a-c. Here, a mixture of acetonitrile and phosphate buffer (10 $\left.\mathrm{mM} \mathrm{KH_{2 }} \mathrm{PO}_{4}\right)(20: 80, \% \mathrm{v} / \mathrm{v})$ was selected as a mobile phase

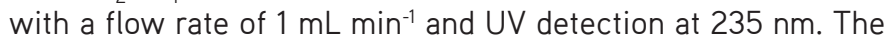
limit of quantification (LOQ) and limit of detection (LOD) were estimated based on the linearity plot (concentration vs. peak area).

\section{Chromatographic conditions}

A Merck-Hibar Purospher STAR Analytical column (C18, 250 mm $\times 4.6 \mathrm{~mm} \times 5 \mu \mathrm{m}$ ) was used for chromatographic separation due to its advantage of having the highest carbon loading for better separation of the desired analyte, minimizing the variabilities of the mode of selection. A mobile phase of acetonitrile and phosphate buffer $\left(10 \mathrm{mM} \mathrm{KH}_{2} \mathrm{PO}_{4}\right)(20: 80 \% \mathrm{v} / \mathrm{v})$ was used. The flow rate was $1 \mathrm{~mL} \mathrm{~min}^{-1}$ with an injection volume of $10 \mu \mathrm{L}$. The oven temperature of the chromatographic column was $30^{\circ} \mathrm{C}$, and the sample temperature was ambient.

Optimization of the chromatographic method using the analytical $Q b D$ approach

Initially, trial and error practices were executed to obtain rigorous data for the selected chromatographic method's performance and its finding of vital independent variables with its considerable effect upon the dependent variables. The utmost significance of developing the RP-HPLC method mostly separates the drug from its excipients and the degradants. Statistical analysis was accomplished by implementing a suitable experimental design by response surface methodology (RSM) through BBD principles. The statistical design intensifies ANOVA principles for establishing the optimized experimental conditions of the method. ${ }^{16,21,22}$ A simple, accurate, and AQbDbased RP-HPLC method was developed, which is also stability indicating. This was further subsequently validated as per the International Conference on Harmonization (ICH) recommended stability guidelines for quantification of abiraterone acetate in its various pharmaceutical formulations (tablets). A mixture of phosphate buffer (10 $\mathrm{mM} \mathrm{KH}_{2} \mathrm{PO}_{4}$ and acetonitrile) (20:80, $\% \mathrm{v} / \mathrm{v}$ ) was used as the mobile phase with a $1 \mathrm{~mL} \mathrm{~min}^{-1}$ flow rate.

\section{Optimized chromatographic conditions}

The optimized conditions are as follows: Optimized trail concentration: $10 \mu \mathrm{g} \mathrm{mL}{ }^{-1}$; flow rate: $1 \mathrm{~mL} \mathrm{~min}^{-1}$; mobile phase: Acetonitrile/phosphate buffer [10 $\left.\mathrm{mM} \mathrm{KH}_{2} \mathrm{PO}_{4^{\prime}}(20: 80) \% \mathrm{v} / \mathrm{v}\right]$. The optimized chromatograms of the blank, standard, and mixture of excipients $\left(10 \mu \mathrm{g} \mathrm{mL}^{-1}\right)$ of the developed analytical method are shown in Figure $2 \mathrm{a}-\mathrm{c}$, respectively.

\section{Method validation}

Method validation was performed to substantiate that the analytical procedure employed for a definite experiment is appropriate for use. ${ }^{19}$ The outcomes of method validation parameters can be highly requisite to judge the reliability, quality, and steadiness of analytical results. Validation of a method for parameters linearity, accuracy, precision, and robustness was done according to recommendations of $\mathrm{ICH}$ guidelines (ICH Q2) (R1). ${ }^{23-25}$ 


\section{Linearity}

The linearity plot of the proposed method was constructed as per the stated ICH guidelines. ${ }^{26-28}$ The linearity chart of abiraterone acetate was found to be within the concentration range of 2-100 $\mu \mathrm{g} \mathrm{mL} \mathrm{L}^{-1}$; further, the calibration plot was constructed using the peak area versus the concentration.

\section{Accuracy}

A series of solutions were spiked with known standard concentrations of abiraterone acetate of $50 \%, 100 \%$, and $150 \%(5,10$, and $15 \mu \mathrm{g} / \mathrm{mL})$ in triplicate, performed as per recommendations of $\mathrm{ICH}$ guidelines. ${ }^{26-28}$

\section{Precision}

The precision of the developed technique, expressed in $\%$ relative standard deviation (RSD), was calculated by performing repeatability and intermediate precision studies. ${ }^{21}$ The developed analytical QbD-based method was validated by the precision studies (both intraday and interday).

\section{$\angle O D$ and $L O Q$}

The LOD and LOQ of the current investigation were evaluated from the baseline noise of abiraterone acetate through comparisons of measured signals of samples with known

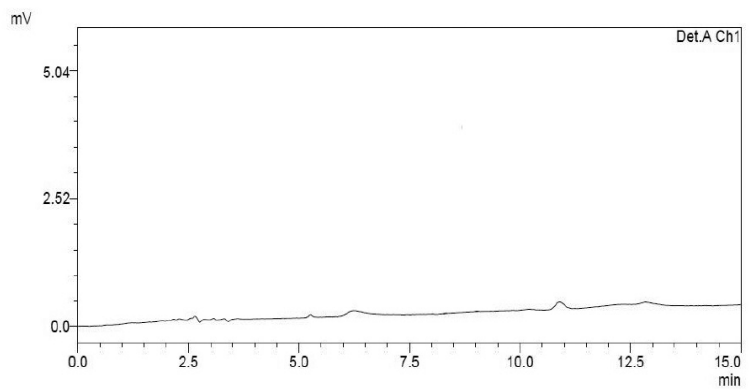

(a)

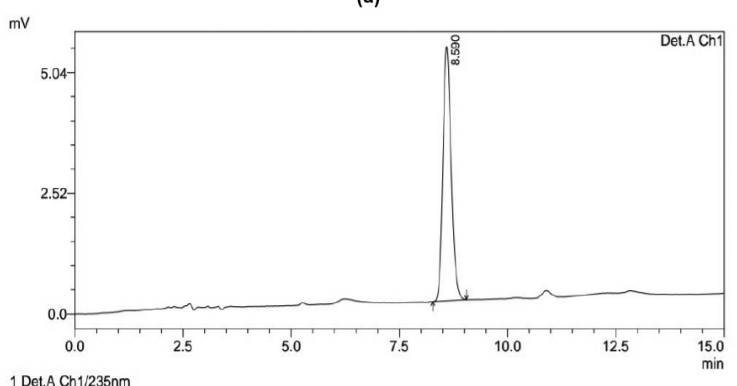

1 Det.A Ch1/235nm

(b)

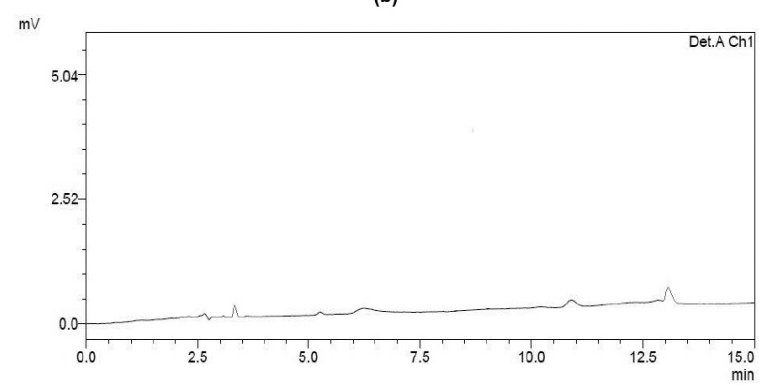

(c)

Figure 2. Optimized chromatograms of blank (a), standard $10 \mu \mathrm{gL} \mathrm{m}^{-1}$, and the mixture of excipients (c) analyte concentrations with that of the blank by (signal-tonoise) S/N ratios of 3:1 (LOD) \& 10:1 (LOQ) as per guidance and protocol recommended by ICHQ2B. ${ }^{29}$

\section{Robustness}

A robustness study was performed to recognize and evaluate the toughness of an analytical method. ${ }^{30}$ To check the ability of the projected method, different factors were deliberately altered such as alternation in mobile phase composition, change in flow rate, etc.

\section{Specificity}

Specificity was carried out to evaluate the analyte noticeably in the occurrence of components that may be expected to be present during development. Specificity was established by representing no interference from the excipients and the degradation products. ${ }^{28,29}$

\section{Forced degradation studies}

Forced degradation generally includes exposure of drug substances to a range of stress conditions to demonstrate the stability profile and possible degradants of developed analytical methods. ${ }^{26-28}$ Acid degradation was performed by adding 1 $\mathrm{mL}$ of $0.1 \mathrm{~N} \mathrm{HCl}$, then heating at $60^{\circ} \mathrm{C}$ for $30 \mathrm{~min}$, cooling to room temperature, and neutralizing. Alkali degradation was performed by adding $1 \mathrm{~mL}$ of $0.1 \mathrm{~N} \mathrm{NaOH}$, heating at $60^{\circ} \mathrm{C}$ for $30 \mathrm{~min}$, cooling to room temperature, and neutralizing. The degradative process through oxidation was performed by exposing the drug to $1 \mathrm{~mL}$ of $3 \% \mathrm{H}_{2} \mathrm{O}_{2}$ and heating at $60^{\circ} \mathrm{C}$ for $30 \mathrm{~min}$. The degradation study was achieved by heating the drug content solutions at $105^{\circ} \mathrm{C}$ on a thermostatically regulated water bath for half an hour. Photolytic degradation was done by subjecting the drug solutions to UV light in a UV chamber at $365 \mathrm{~nm}$ for $3 \mathrm{~h}$. The degradation samples were accurately prepared through appropriate aliquots of the drug and in the solution form of their drug products, instructed by the stress testing protocol. ${ }^{26,29}$ After a definite time, the treated solutions were adjusted with the mobile phase.

\section{Stability of analytical solution}

The solution stability study was effectively performed by observing the standard and sample solutions to determine the stability potential of the drug substance. This factor was analyzed by injecting the drug sample and standard solutions at distinctive intervals. This evaluation parameter is intended for the evaluation of the chemical stability of the drug and sample solution whether any significant changes occurred at varied time intervals. ${ }^{29,31,32}$

\section{Assay of formulations}

Twenty tablets of commercial brands of abiraterone acetate were chosen arbitrarily, and their average weight was determined. ${ }^{31}$ The tablets were crushed to fine powder, $250 \mathrm{mg}$ was weighed, and the powder was dissolved in $200 \mathrm{~mL}$ of acetonitrile (in a $250 \mathrm{~mL}$ volumetric flask). Then, it was shaken for $20 \mathrm{~min}$ and ultrasonicated for $20 \mathrm{~min}$. After that, it was allowed to cool at room temperature, and the solution was diluted up to mark with diluents $\left(1000 \mathrm{mcg} \mathrm{mL}^{-1}\right)$. The final obtained solution was 
then diluted to $10 \mathrm{mcg} \mathrm{mL}^{-1}$ with acetonitrile/phosphate buffer (20:80 \% v/v) and subsequently injected to an HPLC system for estimation in triplicate.

\section{RESULTS AND DISCUSSION}

\section{Method development and optimization Using Box-Behnken experimental design}

In the current investigation, trials were proposed and conducted using Box-Behnken experimental design. ${ }^{21}$ The proposed BBD desires 17 experimental runs of examination to acquire data and model the response surface for a reliable analysis. A $3^{2}$ level with 17 experimental runs was executed to identify the optimized design space for detection of the predicted response. The $3^{2}$ BBD with RSM was executed. ${ }^{16,21}$ The statistical design with optimization methodology and its data analysis through BBD were statistically evaluated using Design-Expert-Ver.12 software..$^{21,22}$ The three most influential factors (CMPs), the composition of the mobile phase (X1), flow rate (X2), and $\mathrm{pH}$ (X3), were selected; the peak area (Y1) and Rt (Y2) were used as observed responses. The design matrix of the statistical BBD and experimental runs are shown in Table $1 .{ }^{21}$ The contour plots illustrate that the effect of both the responses stand in need about factors X1 (acetonitrile and phosphate buffer \%) and $\mathrm{X} 2$ (flow rate), while the $\mathrm{X} 3(\mathrm{pH})$ is found to produce a nullified effect upon the obtained responses. The outline of $3^{2}$ factors and ANOVA results, through its calculated mean and standard deviation values, are summarized in Table $2 .{ }^{22}$ The statistically constructed model was suitably validated by interaction studies using the effect of various factors upon the found responses. The 2D counter plot analysis of peak area and Rt with the observed responses (R1) \& (R2) are depicted in Figure 3a, b, respectively. Similarly, the $3 \mathrm{D}$ counter plot analysis of peak area (R1) response and Rt (R2) response is depicted in Figure $3 c, d$, respectively. The statistical model signifies that predicted values for both the responses (Rt and peak area) are a bit closer to the actual values representing superior accuracy and precision values for the obtained responses. The $2 D$ and $3 D$ counter plots of predicted versus actual values for peak area

Table 1. Box-Behnken design experimental runs by selecting $3^{2}$ factors

\begin{tabular}{|c|c|c|c|c|c|}
\hline Serial no & $\begin{array}{l}\text { Factor 1: Mobile phase } \\
\text { composition }(\% \mathrm{v} / \mathrm{v})\end{array}$ & Factor 2: Flow rate $(\mathrm{mL} / \mathrm{min})$ & Factor 3: $\mathrm{pH}$ & Response 1 peak area & $\begin{array}{l}\text { Response } 2 \\
\text { retention time }\end{array}$ \\
\hline 1 & 50 & 1.5 & 6 & 32909 & 8.59 \\
\hline 2 & 50 & 1.25 & 5 & 109912 & 10.124 \\
\hline 3 & 50 & 1.25 & 5 & 329581 & 11.457 \\
\hline 4 & 50 & 1 & 4 & 699272 & 8.59 \\
\hline 5 & 80 & 1.5 & 5 & 139884 & 12.321 \\
\hline 6 & 80 & 1.25 & 6 & 559463 & 9.125 \\
\hline 7 & 80 & 1 & 5 & 745612 & 12.581 \\
\hline 8 & 50 & 1 & 6 & 411153 & 10.235 \\
\hline 9 & 20 & 1.5 & 5 & 325114 & 7.235 \\
\hline 10 & 50 & 1.25 & 5 & 451231 & 6.512 \\
\hline 11 & 20 & 1.25 & 6 & 521231 & 5.236 \\
\hline 12 & 50 & 1.25 & 5 & 425851 & 6.458 \\
\hline 13 & 50 & 1.25 & 5 & 456875 & 7.126 \\
\hline 14 & 50 & 1.5 & 4 & 612578 & 8.127 \\
\hline 15 & 20 & 1 & 5 & 661257 & 9.245 \\
\hline 16 & 80 & 1.25 & 4 & 457812 & 8.736 \\
\hline 17 & 20 & 1.25 & 4 & 489254 & 7.984 \\
\hline
\end{tabular}

Table 2. ANOVA by selecting $3^{2}$ factors

\begin{tabular}{llllllllll} 
Factors & Name & Units & Type & Minimum & Maximum & Coded low & Coded high & $\begin{array}{l}\text { Mean } \\
\text { deviation }\end{array}$ \\
\hline A & $\begin{array}{l}\text { Mobile phase } \\
\text { composition }\end{array}$ & $\% \mathrm{v} / \mathrm{v}$ & Numeric & 20.00 & 80.00 & $1-20.00$ & $1-80.00$ & 50.00 & 21.21 \\
\hline B & Flow rate & $\mathrm{mL} / \mathrm{min}$ & Numeric & 1.0000 & 1.50 & $1-1.00$ & $1-80.00$ & 1.25 & 0.1768 \\
\hline C & $\mathrm{pH}$ & Moles/ltr & Numeric & 4.00 & 6.00 & $1-4.00$ & $1-80.00$ & 5.00 & 0.7071 \\
\hline
\end{tabular}


(R1) and Rt (R2) are depicted in Figure 4a, b, respectively. The perturbation plot displays the impact of all the influential factors (mobile phase and flow rate) at a particular point within the design space for the selected responses peak area and Rt. The representative plots of perturbation analysis for the

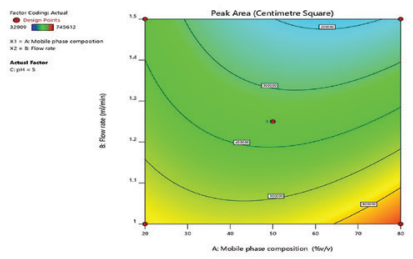

(a)

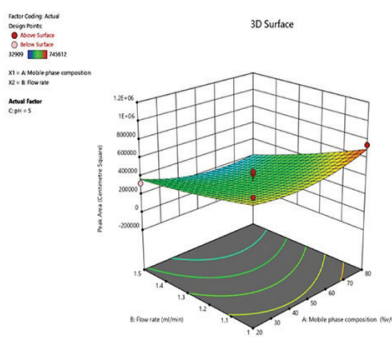

(c)
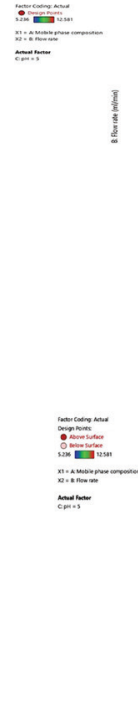

(d)
Figure 3. 2D surface contour plots of peak area (R1) response (a) and retention time (R2) response (b); 3D surface contour plots of peak area (R1) response (c) and retention time (R2) response (d)

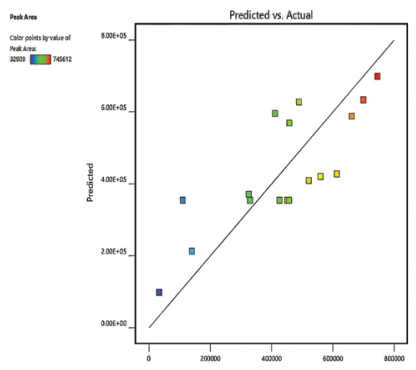

(a)

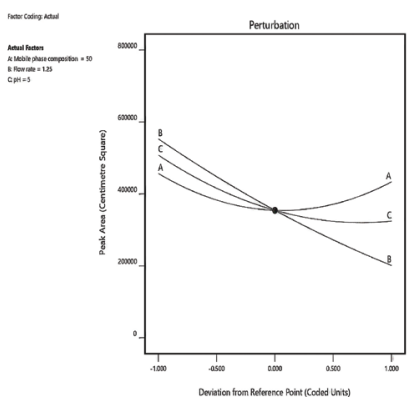

(c)

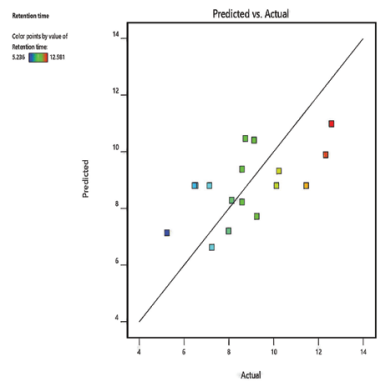

(b)
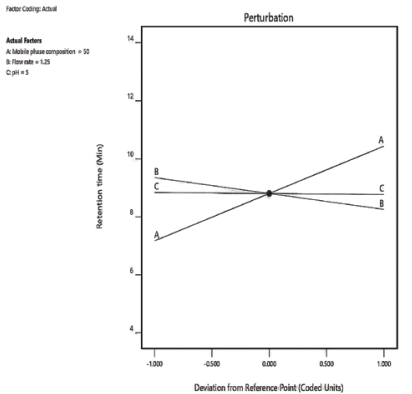

(d)
Figure 4. Predicted versus actual values for peak area (R1) (a) and predicted versus actual values for retention time (R2) (b). Representative plots of perturbation for $(c)$ response peak area (R1) and (d) retention time (R2) observed responses peak area (R1) and Rt (R2) are depicted in Figure 4c, d, respectively. Here, for $2 D$ and $3 D$ surface numerical optimization, the Rt (R2) and peak area (R1) are depicted in Figure 5a-d, respectively. Figure 6 elucidates the parameters intended for numerical optimization for desirability and optimized data for factors indorsed by design. Finally, the optimized apparent chromatographic conditions can be well predicted from the arithmetical model, and it has strongly been recommended for the developed analytical method (Table 3 ).

\section{Results of validation studies}

The optimized feasible chromatographic conditions were aggrandized and effectively implemented to validate the $\mathrm{QbD}$ based method by a range of validation parameters, linearity, accuracy, precision, LOD, LOQ, robustness, etc., as per recommendations of $\mathrm{ICH}$ guidelines.

\section{Linearity}

Six concentrations of the abiraterone acetate working standard ranging from 2 to $100 \mathrm{ppm}$ were prepared and analyzed for the linearity study. The calibration plot was constructed by plotting the chromatographic peak areas versus the known predicted concentrations in $\mu \mathrm{g} \mathrm{mL}^{-1}$, and values of observed concentrations were determined. The regression equation was found to be $Y=73399 x-71154$, and the regression coefficient $r^{2}$ is 0.998 . The detail of the calibration plot and its residual plot data analysis are depicted in Figure 7a, b, respectively.

\section{Accuracy}

The accuracy of the developed method was studied to make sure the agreement between the true and reference values in

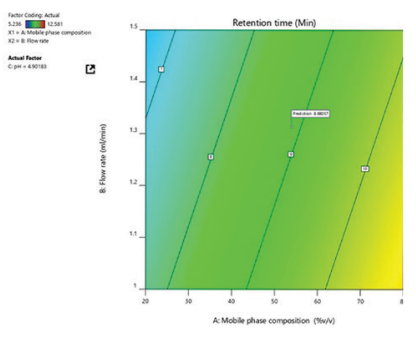

(a)

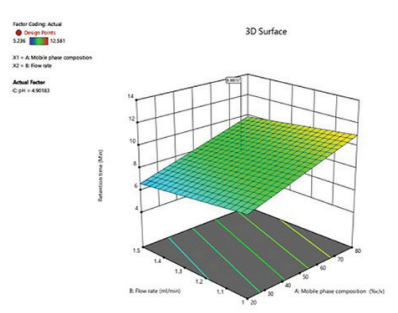

(c)
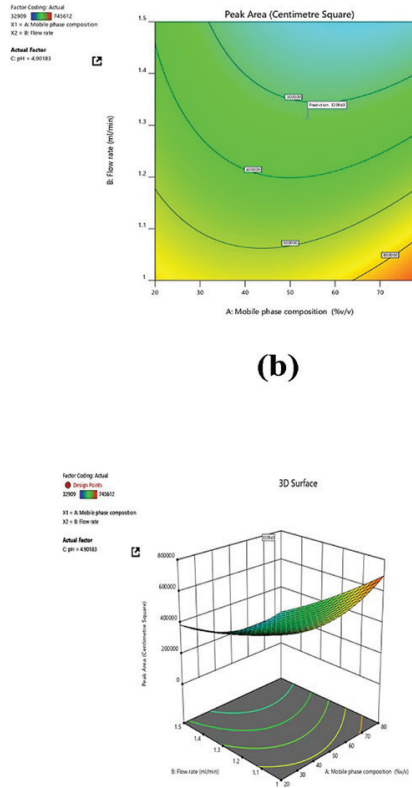

(d)
Figure 5. 2D surface numerical optimization for retention time (R2) (a) and peak area (R1) (b); 3D surface numerical optimization for retention time (R2) (c) and peak area (R1) (d) 
three significant levels of $50 \%, 100 \%$, and $150 \%$. The percentage recoveries of three various concentrations were found to be within the range of $98 \%$ to $102 \%$, and $\%$ RSD was obtained within the acceptance limit, that is, NMT 2.0\%. The data of all the recovery studies are shown in Table 4.

\section{Precision}

Precision studies of the developed method were carried out by the system, method, and intermediate precision studies. Precision of the system suitability test for six replicate standard injections was calculated, within the acceptance criteria, that is, NMT $2 \%$, and both intraday and interday precisions through three replicate injections of standards were calculated. Data of $\%$ RSD are reported in Table 5.

\section{$\angle O D$ and $L O Q$}

The detection and quantification limits ( $L O D \& \& O Q$ ) of the current investigation were actively quantified as per the recommendation of ICHQ2B guidelines for validation of analytical methodology. The detection limit was derived as a signal-to-noise (S/N) ratio of 3:1, whereas the quantification limit was indicated as a $\mathrm{S} / \mathrm{N}$ ratio of $10: 1$, as an effect of the

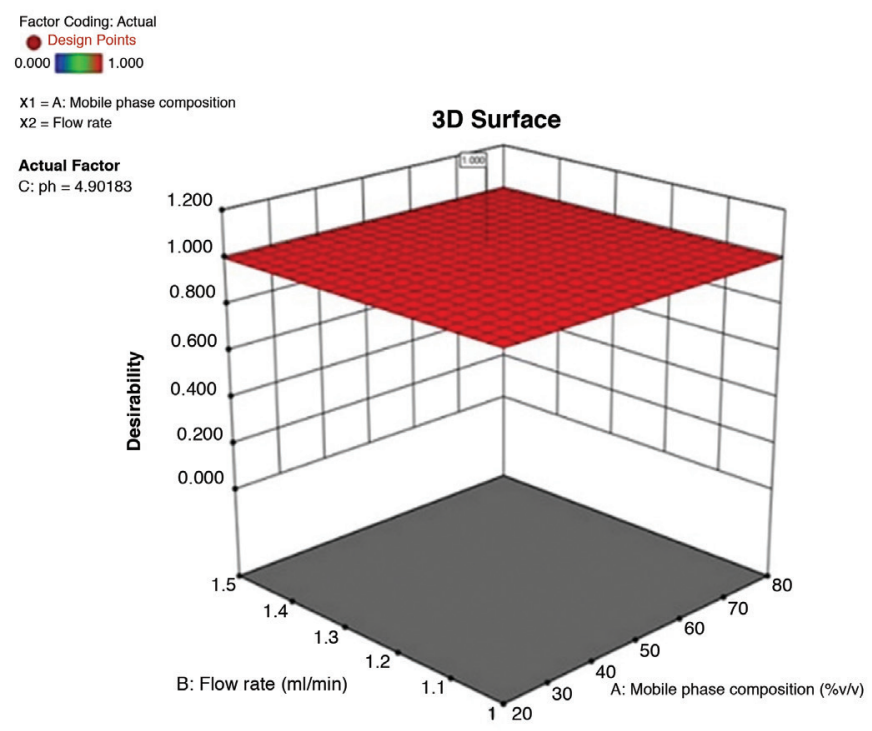

Figure 6. Numerical optimization for desirability data

a

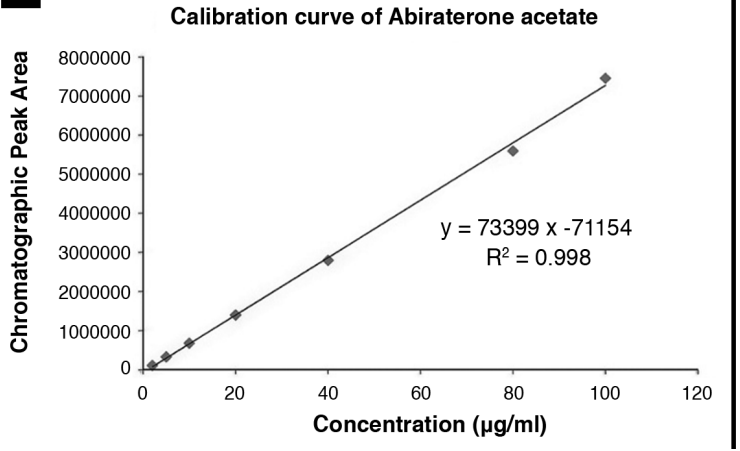

response by the detector. The estimated value for LOD was found to be $0.45 \mathrm{ppm}$, and the estimated value for LOQ was 1.35 $\mathrm{ppm}$. The calculated values are shown in Table $3 .{ }^{23}$

\section{Robustness}

Robustness is the capacity to replicate the analytical method in diverse labs or under varied conditions without the manifestation of unanticipated differences in the obtained results. The estimated values of mobile phase composition and flow rates were taken, and changes in flow rate and mobile phase data are summarized in Table 6 . The results show the calculated \% RSD within the acceptance limit, that is, less than $2 \%$.

\section{Specificity}

The specificity of the method has been studied to determine the interference from the degradation products as per ICH through a forced degradation study. The results denote no sign of peak formation at the Rt of abiraterone acetate and the case of degradation products since the peak purity passed. The data reveal that the purity angle was less than the purity threshold, presenting no specific interference (Table 7 ).

\section{Table 3. Optimum chromatographic conditions of abiraterone} acetate

Optimum chromatographic conditions

\begin{tabular}{ll}
\hline Run time & 15.0 minute \\
\hline Retention time & 8.59 minutes \\
\hline Flow rate & $1 \mathrm{~mL} / \mathrm{min}$ \\
\hline Linearity range & $\begin{array}{l}(2-100) \mu \mathrm{g} / \mathrm{mL} \\
\left(r^{2}=0.998\right)\end{array}$ \\
\hline Accuracy & $\begin{array}{l}\% \text { recovery: Within }(98-102 \%) \\
(\mathrm{RSD}<2 \%)\end{array}$ \\
\hline Precision & $(\mathrm{RSD}<2 \%)$ \\
\hline LOD & $0.45 \mu \mathrm{g} / \mathrm{mL}$ \\
\hline LOQ & $1.35 \mu \mathrm{g} / \mathrm{mL}$ \\
\hline
\end{tabular}

RSD: Relative standard deviation, LOD: Limit of detection, LOQ: Limit of quantification

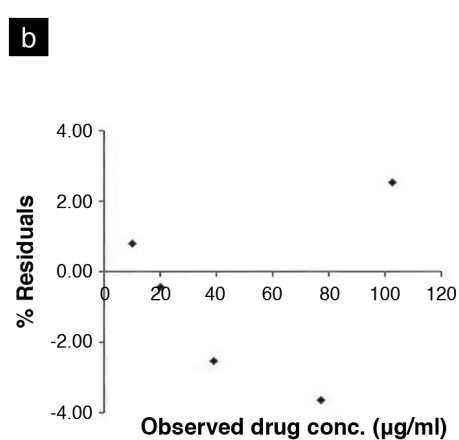

Figure 7. Schematic diagram of calibration plot (a) and residual plot (b) of abiraterone acetate 
Table 4. Accuracy data of abiraterone acetate

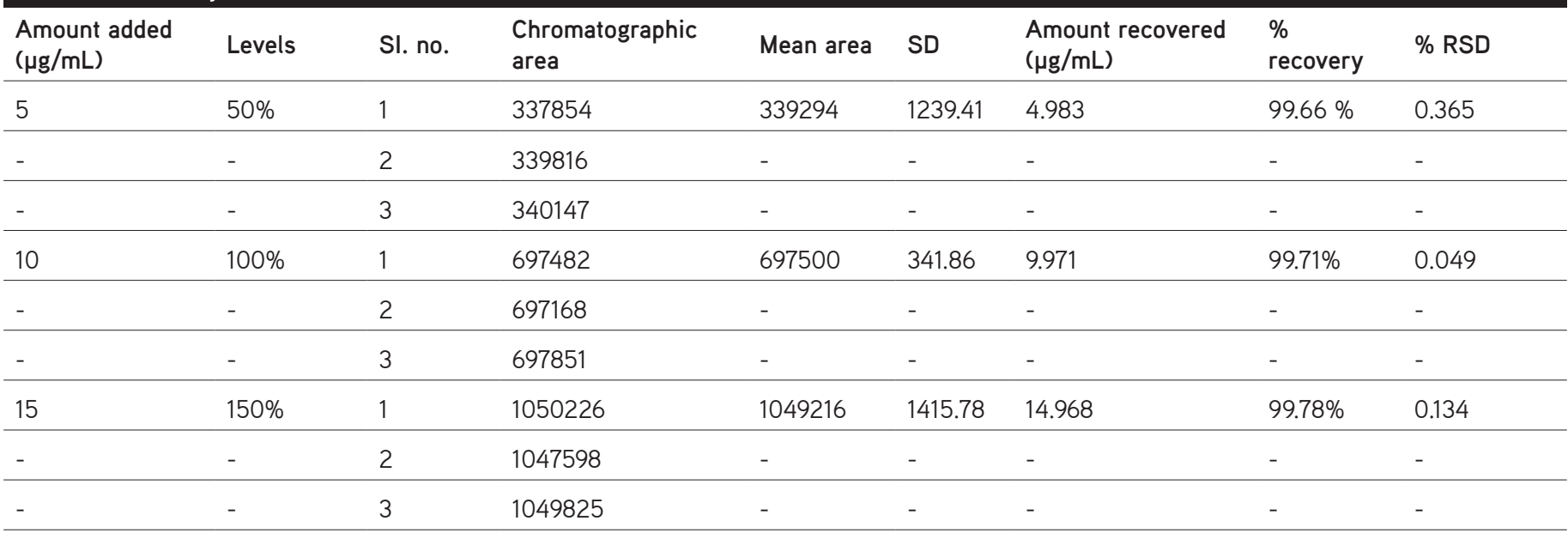

RSD: Relative standard deviation, SD: Standard deviation

Table 5. Standard injection of abiraterone acetate peak response by system, intra, and interday precision tests System precision Intra-day Inter-day

\begin{tabular}{|c|c|c|c|c|c|c|c|c|c|c|c|}
\hline \multirow{2}{*}{ Conc. $(\mu \mathrm{g} / \mathrm{mL})$} & \multirow{2}{*}{$\begin{array}{l}\text { Peak } \\
\text { area }\end{array}$} & \multirow{2}{*}{$\begin{array}{l}\text { USP } \\
\text { tailing }\end{array}$} & \multirow{2}{*}{$\begin{array}{l}\text { USP } \\
\text { plate } \\
\text { count }\end{array}$} & \multirow{2}{*}{$\begin{array}{l}\text { Conc. } \\
(\mu \mathrm{g} / \mathrm{mL})\end{array}$} & \multicolumn{3}{|c|}{$\begin{array}{l}\text { Peak area of at different time } \\
\text { intervals (day } 1 \text { ) }\end{array}$} & \multirow[t]{2}{*}{$\begin{array}{l}\text { Conc. } \\
(\mu \mathrm{g} / \mathrm{mL})\end{array}$} & \multicolumn{3}{|c|}{$\begin{array}{l}\text { Peak area of at different time } \\
\text { intervals (day 2) }\end{array}$} \\
\hline & & & & & 10 a.m & 2 p.m & 5 p.m & & 10 a.m & 2 p.m & 5 p.m \\
\hline 10 & 695445 & 1.01 & 7486 & 5 & 329851 & 326885 & 327519 & 5 & 326511 & 326578 & 326899 \\
\hline 10 & 695872 & 1.02 & 7453 & 5 & 329557 & 326699 & 327157 & 5 & 326789 & 326576 & 326858 \\
\hline 10 & 695234 & 1.01 & 7359 & 5 & 329259 & 326544 & 327556 & 5 & 326724 & 326544 & 326891 \\
\hline 10 & 695982 & 1.03 & 7422 & Average & 329556 & 326709.3 & 327411 & Average & 326675 & 326566 & 326883 \\
\hline \multirow{3}{*}{10} & \multirow{3}{*}{695971} & \multirow{3}{*}{1.02} & \multirow{3}{*}{7356} & SD & 296.00 & 170.73 & 220.46 & SD & 145.418 & 19.079 & 21.733 \\
\hline & & & & $\%$ RSD & 0.09 & 0.05 & 0.07 & \% RSD & 0.045 & 0.006 & 0.007 \\
\hline & & & & 10 & 695272 & 698777 & 697651 & 10 & 696565 & 694872 & 697981 \\
\hline \multirow{2}{*}{10} & \multirow{2}{*}{695332} & \multirow{2}{*}{1.03} & \multirow[b]{2}{*}{7287} & 10 & 695773 & 698874 & 697236 & 10 & 696834 & 698671 & 697123 \\
\hline & & & & 10 & 695859 & 698349 & 697987 & 10 & 696785 & 698956 & 697855 \\
\hline Average & 695639 & & & Average & 695635 & 698667 & 697625 & Average & 696728 & 697500 & 697653 \\
\hline SD & 340.02 & & & SD & 317.01 & 279.35 & 376.19 & SD & 143.27 & 2280.08 & 463.30 \\
\hline \multirow[t]{7}{*}{$\%$ RSD } & 0.0489 & & & $\%$ RSD & 0.05 & 0.04 & 0.05 & $\%$ RSD & 0.02 & 0.33 & 0.07 \\
\hline & & & & 20 & 1373567 & 1398971 & 1385569 & 20 & 1398171 & 1373267 & 1385669 \\
\hline & & & & 20 & 1373776 & 1398885 & 1386981 & 20 & 1398985 & 1373976 & 1385781 \\
\hline & & & & 20 & 1373962 & 1398934 & 1385856 & 20 & 1398734 & 1373562 & 1385113 \\
\hline & & & & Average & 1373768 & 1398930 & 1386135 & Average & 1398630 & 1373602 & 1385521 \\
\hline & & & & SD & 197.61 & 43.14 & 746.30 & SD & 416.85 & 356.16 & 357.75 \\
\hline & & & & \% RSD & 0.01 & 0.03 & 0.05 & \% RSD & 0.03 & 0.03 & 0.03 \\
\hline
\end{tabular}

RSD: Relative standard deviation, SD: Standard deviation 


\section{Table 6. Robustness data of abiraterone acetate}

Robustness

\begin{tabular}{|c|c|c|c|c|}
\hline \multirow{4}{*}{$\begin{array}{l}\text { Flow rate }(1+0.2 \mathrm{~mL} / \mathrm{min}) \\
10(\mu \mathrm{g} / \mathrm{mL})\end{array}$} & Peak area & Average & SD & $\%$ RSD \\
\hline & 689234 & 689558 & 384.448 & 0.05575 \\
\hline & 689458 & - & - & - \\
\hline & 689983 & - & - & - \\
\hline \multirow{3}{*}{$\begin{array}{l}\text { Flow rate }(1-0.2 \mathrm{~mL} / \mathrm{min}) \\
10(\mu \mathrm{g} / \mathrm{mL})\end{array}$} & 699764 & 699770 & 85.675 & 0.01224 \\
\hline & 699859 & - & - & - \\
\hline & 699688 & - & - & - \\
\hline \multirow{3}{*}{$\begin{array}{l}\text { Amount of }(A C N+2 \% v / v) \\
10(\mu \mathrm{g} / \mathrm{mL})\end{array}$} & 699272 & 699641 & 323.013 & 0.04617 \\
\hline & 699874 & - & - & - \\
\hline & 699776 & - & - & - \\
\hline \multirow{3}{*}{$\begin{array}{l}\text { Amount of }(A C N-2 \% v / v) \\
10(\mu g / m L)\end{array}$} & 685761 & 686455 & 748.890 & 0.1090 \\
\hline & 686357 & - & - & - \\
\hline & 687249 & - & - & - \\
\hline \multirow{3}{*}{$\begin{array}{l}\text { Detector wavelength } 235 \mathrm{~nm} \\
(+2 \mathrm{~nm})\end{array}$} & 689071 & 689068 & 301.506 & 0.0437 \\
\hline & 689369 & - & - & - \\
\hline & 688766 & - & - & - \\
\hline \multirow{3}{*}{$\begin{array}{l}\text { Detector wavelength } 235 \mathrm{~nm} \\
(-2 \mathrm{~nm})\end{array}$} & 683866 & 684357 & 687.714 & 0.10049 \\
\hline & 684062 & - & - & - \\
\hline & 685143 & - & - & - \\
\hline
\end{tabular}

RSD: Relative standard deviation, SD: Standard deviation

Table 7. Forced degradation and solution stability data of abiraterone acetate

\begin{tabular}{|c|c|c|c|c|c|c|c|}
\hline Stress conditions & Peak area & $\begin{array}{l}\text { *Drug recovered } \\
(\%)\end{array}$ & $\begin{array}{l}{ }^{*} \text { Drug } \\
\text { decomposed (\%) }\end{array}$ & $\begin{array}{l}\text { Theoretical } \\
\text { plates }\end{array}$ & $\begin{array}{l}\text { Tailing } \\
\text { factor }\end{array}$ & $\begin{array}{l}\text { Purity } \\
\text { angle }\end{array}$ & $\begin{array}{l}\text { Purity } \\
\text { threshold }\end{array}$ \\
\hline $\begin{array}{l}\text { Abiraterone acetate standard } \\
\text { (control) }\end{array}$ & 698252 & 100 & - & 7526 & 1.08 & 0.301 & 0.425 \\
\hline $\begin{array}{l}\text { Acidic degradation } \\
1 \mathrm{~mL} 0.1 \mathrm{~N} \mathrm{HCl}, 60^{\circ} \mathrm{C}, 30 \text { minutes }\end{array}$ & 513215 & 73.5 & 26.5 & 6326 & 1.29 & 0.118 & 0.192 \\
\hline $\begin{array}{l}\text { Alkaline degradation } \\
0.1 \mathrm{~mL} 0.1 \mathrm{~N} \mathrm{NaOH}, 60^{\circ} \mathrm{C}, 30 \\
\text { mins }\end{array}$ & 612367 & 87.7 & 12.3 & 6823 & 1.24 & 0.356 & 0.526 \\
\hline $\begin{array}{l}\text { Oxidative degradation } \\
1 \mathrm{~mL} 3 \% \mathrm{H}_{2} \mathrm{O}_{2}, 60^{\circ} \mathrm{C}, 30 \text { minutes }\end{array}$ & 686381 & 98.3 & 1.7 & 7067 & 1.21 & 0.319 & 0.423 \\
\hline $\begin{array}{l}\text { Thermal degradation } 105^{\circ} \mathrm{C}, 30 \\
\text { minutes }\end{array}$ & 692666 & 99.2 & 0.8 & 7236 & 1.12 & 0.238 & 0.469 \\
\hline
\end{tabular}

Solution stability data

\section{Area counts}

Time (hrs)

Initial

$7 \mathrm{hrs}$

16 hrs

$25 \mathrm{hrs}$

$32 \mathrm{hrs}$

$40 \mathrm{hrs}$

*With respect to assay value of control
$\%$ Deviation from mean: $\pm 3.0 \%$

\begin{tabular}{cc} 
Standard & Sample \\
\hline 695773 & 686747 \\
\hline 694105 & 686875 \\
\hline 697297 & 689303 \\
\hline 698567 & 689473 \\
6999875 & 692615 \\
6999948 & 698543 \\
\hline
\end{tabular}

Standard

Sample

0.0

0.01

0.23

0.37

0.39

0.85

1.71 


\section{Forced degradation studies}

Forced degradation studies provide knowledge on practical degradation pathways and degradation products of the active ingredients and help expound the configuration of the degradants as per $\mathrm{ICH}$ recommendations. ${ }^{27}$ The following conditions were applied for degradation: Acid $\left(1 \mathrm{~mL}\right.$ of $0.1 \mathrm{~N} \mathrm{HCl}, 60^{\circ} \mathrm{C}$ for 30 $\mathrm{min}$ ), alkali ( $1 \mathrm{~mL}$ of $0.1 \mathrm{~N} \mathrm{NaOH}, 60^{\circ} \mathrm{C}$ for $30 \mathrm{~min}$ ), peroxide (1 $\mathrm{mL}$ of $\left.3 \% \mathrm{v} / \mathrm{v} \mathrm{H}_{2} \mathrm{O}_{2}\right)$, thermal $\left(105^{\circ} \mathrm{C}\right.$ ), and photolytic degradations at $231 \mathrm{~nm}$, for determining the steady nature of drugs. Percent drug degradation values during acidic and alkaline degradation were observed to be $26.5 \%$ and $12.3 \%$, respectively. In contrast, less than $2 \%$ degradation was reported in the case of oxidative, thermal, and photolytic degradations, which indicate the drug's completely resistant behaviors to the above stress conditions. The detailed descriptions of forced degradation activities are

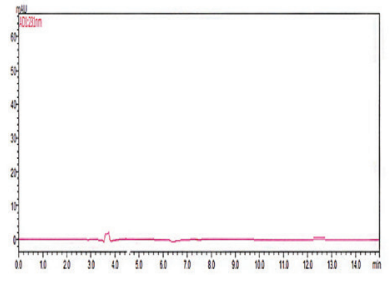

(a)

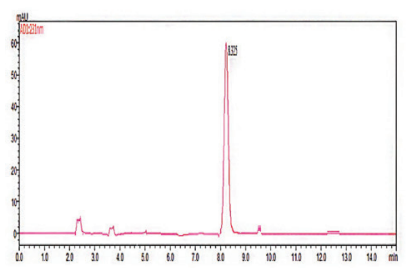

(c)

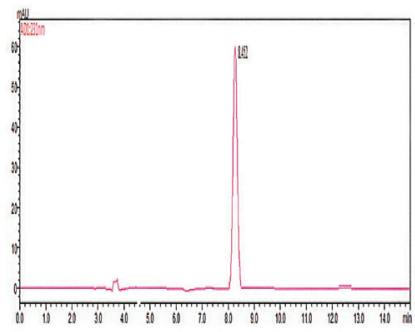

(e)

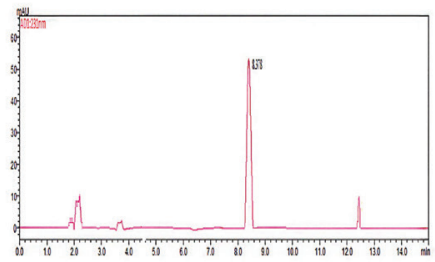

(b)

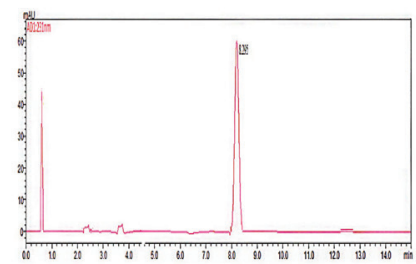

(d)

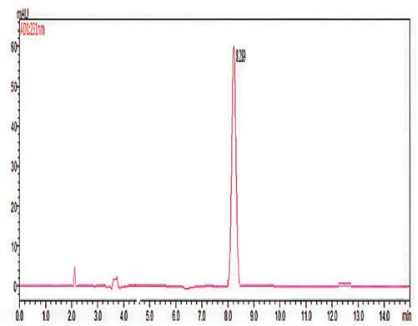

(f)
Figure 8. Schematic diagram indicating (a) the mixture of excipients, (b) sample acidic degradation, (c) alkali degradation, (d) peroxide degradation, (e) photolytic degradation, and ( $f$ ) thermal degradation studies listed in Table 7 . The representative chromatograms of the sample in various stress conditions by incorporating a mixture of excipients (a), acid (b), alkali (c), oxidative (d), photolytic (e), and thermal degradation ( $f$ ) studies are depicted in Figure 8a-f, respectively.

\section{Stability of analytical solution}

The solution stability study was carried out by observance of sample and standard solutions at $25 \pm 2^{\circ} \mathrm{C}$ for $40 \mathrm{~h}$. After analysis, it has been concluded that the drug standard and sample were stable for up to $40 \mathrm{~h}$ (Table 7). The anticipated method was effectively validated and met the necessities as per the recommended stability guidelines of $\mathrm{ICH}$.

\section{Assay of formulations}

The chromatogram of the marketed sample is depicted in Figure 9. The calculated values of the percentage of the assay of various marketed formulations are exhibited in Table 8. The results show that all the values of the formulations are within the acceptance limit, that is, $98-102 \%$.

\section{CONCLUSION}

Chemometrics-assisted method development affords regulatory flexibility, the formation of homogeneous or robust finished products of assured quality characteristics as per Food and Drug Administration (FDA) concerns, and ICH stability stressed conditions. In addition to this, the $A Q b D$ method minimizes the process of revalidation, lessens solvent consumption and development time, and enhances optimum robust analytics. By implementing the DoE, the Box-Behnken statistical design can evaluate the independent variables (CMPs) concurrently with adding common interactions among the critical factors to optimize the tentative conditions. It is explicit that the application of this BBD with RSM is an adaptable practice to reduce the

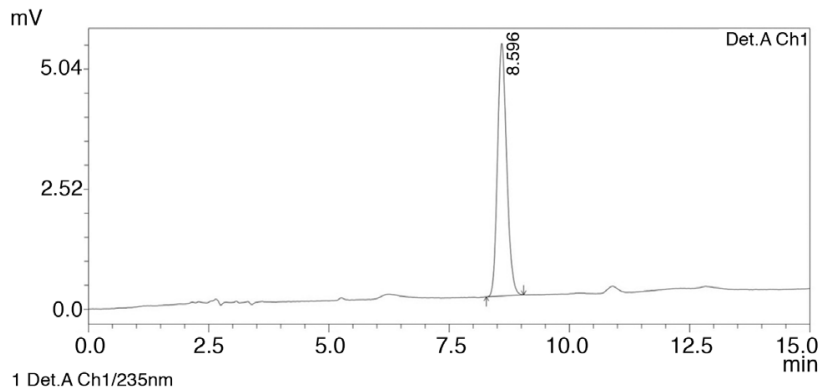

Figure 9. Chromatogram of the formulation $\left(10 \mu \mathrm{gLL}^{-1}\right)$

Table 8. Assay data of abiraterone acetate

Assay of marketed formulations

\begin{tabular}{llll}
\hline Brand name & Label claim $(\mathrm{mg})$ & Drug obtained & \% Recovery \\
\hline Brand I (XIBRA) & 250 & 247.96 & 99.18 \\
\hline Brand II (ZYTIGA) & 250 & 251.02 & 100.41 \\
\hline Brand III (ABIRAPRO) & 250 & 249.47 & 99.79 \\
\hline
\end{tabular}


total experimental runs to obtain sustainable, robust analytics, reducing the chance of revalidation, requisite for analytical development. The optimization of the RP-HPLC method for abiraterone acetate can produce the highest intense data and boost efficiency within a short period as per the ICH Q8 (R2) and FDA perspectives. The proposed method was found to be linear, with concentrations of 2-100 ppm having $r^{2}$ : 0.998. The remarkable \% recovery (within $98-102 \%$ ) of the drug reflects that the excipients existing in the tablet formulation have no impediment in the quantitation of the drug. The optimized conditions by $A Q b D$ of the anticipated method established that the proposed study was cost-effective, extremely robust, and stability indicating. Therefore, the developed stabilityindicating method was economical, accurate, and precise. It can be successfully implemented for the routine analysis of abiraterone acetate in its bulk and pharmaceutical formulations.

\section{ACKNOWLEDGMENTS}

The authors are thankful to the Board of Management, School of Pharmacy and Life Sciences, Centurion University, Bhubaneswar, India, and the Principal of KL College Pharmacy, KL University (Deemed to be University), Vaddeswaram, Guntur, India, for providing the suitable instrumental facilities to carry out the research activities.

Conflict of interest: No conflict of interest was declared by the authors. The authors are solely responsible for the content and writing of this paper.

\section{REFERENCES}

1. ONDQA Division Director's Memo. Abiraterone Acetate. Last Accessed Date: 08.04.2011. Available from: https://www.accessdata.fda.gov/ drugsatfda_docs/nda/2011/2023790rig1s000ChemR.pdf

2. CFDER. Chemistry Review (S). US Department of Health and Human Services. Last Accessed Date: December 2011. Available from: https:// www.scirp.org/reference/ReferencesPapers.aspx?ReferencelD= 1022929

3. Oxidation stability of abiraterone acetate. Last Accessed Date: 25.01.2014. Available from: https://patents.google.com/patent/W02014009437A1/en

4. ZYTIGA ${ }^{\text {mI }}$ (abiraterone acetate) Tablets. Last Accessed Date: 21.04.2018. Available from: http://specialtydrug.magellanprovider.com/ media/116104/ih_mrxm_abiraterone_05_19.pdf

5. FDA approves Abiraterone for Treatment of Men with Advanced Prostate Cancer. Last Accessed Date: 08.02.2018. Available from: https://www. cancer.gov/news-events/cancer-currents blog/2018/abiraterone-fdaprostate-hormone-sensitive

6. Khdera A, Darwish I, Bamanea F. Analysis of Abiraterone stress degradation behavior using liquid chromatography coupled to ultraviolet detection and electrospray ionization mass spectrometry. J Pharm Biomed Anal. 2013;23:74-77.

7. Martins V, Asad Y, Wilsher N, Raynaud F. A validated liquid chromatographic-tandem mass spectroscopy method for the quantification of abiraterone acetate and abiraterone in human plasma. $J$ Chromatogr B Anal Technol Biomed Life Sci. 2006;843:262-267.
8. Annapurna MM, Pradhan D, Routh KC. Stability Indicating RP-HPLC method for the determination of Abiraterone (An Anti-Cancer Drug). Res J Pharm Tech. 2018;11:3007-3012.

9. Punde SR, Farooqui J, Zainuddin M, Rajagopal S, Mullangi R. Development and validation of a highly sensitive method for the determination of Abiraterone in rat and human plasma by LC-MS/ MS-ESI: application to a pharmacokinetic study, Biomed Chromatogr. 2012;26:761-768.

10. Gong $A$, Zhu X. $\beta$-cyclodextrin sensitized spectrofluorimetric for the determination of Abiraterone Acetate and Abiraterone. J Fluoresce. 2013;23:1279-1286.

11. Belleville $T$, Noe G, Huillard $O$, Thomas-Schoemann A, Vidal M, Goldwasser F, Alexandre J, Blanchet B. A HPLC-fluorescence method for the quantification of Abiraterone in plasma from patients with metastatic castration-resistant prostate cancer. J Chromatogr B Anal Technol Biomed Life Sci. 2015;989:86-90.

12. Kumar SV, Rudresha G, Gaurav S, Zainuddin, Dewang P, Kethiri RR, Rajagopal S, Mullangi R. Validated RP-HPLC/UV method for the quantitation of Abiraterone in rat plasma and its application to a pharmacokinetic study in rats. Biomed Chromatogr. 2013;27:203-207.

13. Swain S, Parhi R, Jena BR, Manohar BS. Quality by design: concept to applications. Curr Drug Discov Technol. 2019;16:240-250.

14. Stat-ease. 2019. Design-Expert ${ }^{\circledR}$ Software Version 12 - Stat-Ease. Last Accessed Date: 21.04.2018. Available from: https://www.statease.com/ software/design-expert/

15. The United States Pharmacopeia. The National Formulary, USP 37/NF 32, 2014. Available from: http://dl-book.ir/dl/usp/USP38.pdf

16. Podczeck F. Pharmaceutical Experimental Design, G.A. Lewis, D. Mathieu, and R. Phan-Tan-Lu, Marcel Dekker, Inc., New York, 1999, 498 pages, ISBN 0-8247-9860-0. 1999;182:127-128. Available from: https:// www.sciencedirect.com/science/article/abs/pii/S037851739900068X

17. Bezerra MA, Santelli RE, Oliveira EP, Villar LS, Escaleira LA. Response surface methodology (RSM) as a tool for optimization in analytical chemistry. Talanta. 2008;76:965-977.

18. Massart DL, Vandeginste BGM, Buydens LMC, Jong de S, Lewi PJ, Smeyers-Verbeke J. Handbook of Chemometrics and Qualimetrics: Part A. Amsterdam: Elsevier; 1977.

19. Zolgharnein J, Shahmoradi A, Ghasemi JB. Comparative study of Box-Behnken, central composite, and Doehlert matrix for multivariate optimization of $\mathrm{Pb}(\mathrm{II})$ adsorption onto Robinia tree leaves. J Chemometr. 2013;27:12-20.

20. Nethercote P, Ermer J. Quality by design for analytical methods: implications for method validation and transfer. Pharm Technol. 2012;36:74-79.

21. Manohar M, Joseph J, Selvaraj T, Sivakumar D. Application of BoxBehnken design to optimize the parameters for turning Inconel 718 using coated carbide tools. Int J Sci Eng Res. 2013;4:620.

22. Box-Behnken Designs for Optimizing Product Performance. 2019. Last Accessed Date: 14.12.2011. Available from: https://www.Weilbull.com

23. Lavanya G, Sunil M, Eswarudu MM, Eswaraiah MC, Harisudha K, Spandana BN. Analytical method validation: an updated review. Int J Pharm Sci Res. 2013;4:1280-1286.

24. ICH. In: International Conference on Harmonization of Technical Requirements for Registration of Pharmaceuticals for Human Use, Validation of analytical procedures: text and methodology Q2(R1), ICH Steering Committee, Geneva, Switzerland, 2005. 
25. U.S. FDA. Guidance for Industry (draft): Analytical Procedures and Methods Validation: Chemistry, Manufacturing, and Controls and Documentation 2000.

26. International conference on Harmonization, Guidance for Industry In: Q2B Validation of Analytical Procedures, Methodology, Switzerland, IFPMA, 1996.

27. International conference on Harmonization, Guidance for Industry In: Q2A Text on Validation of Analytical Methods, Switzerland, IFPMA, 1994.

28. Iyer S. Validation of analytical Procedure. Guidelines on CGMP and Quality of Pharmaceutical Products. 1st ed. London: D. K Publications; 2002:145-150.
29. Panchumarthy R, Navya CN, Pravallika D, Navya Sri D. A review on stepby-step analytical method validation. IOSR J Pharm. 2015;5:7-19.

30. Crowther JB. (ed). Validation of Pharmaceutical Test Methods, in Handbook of Modern Pharmaceutical Analysis. New York: Academic Press; 2001:415-443.

31. USP Pending Monograph-Abiraterone acetate Tablets.v Last Accessed Date: 25.01.2019. Available from: https://www.uspnf.com/sites/default/ files/usp_pdf/EN/USPNF/revisions/abiraterone-acetate-tabs-rbnotice-20191118.pdf

32. Aubry, AF, Tattersall, P, and Ruan, J. Development of Stability Indicating Methods. In: Huynh-Ba K, ed. Handbook of Stability Testing in Pharmaceutical Development. New York: Springer; 2009;139-161. 